\title{
Syntactical Error Analysis on Conjunctional Students' English Narrative Composition
}

\author{
Andi Santoso', M. Rinzat Iriyansah ${ }^{2}$ \\ Universitas Indraprasta PGRI \\ Iandynabil@gmail.com, ${ }^{2}$ rinzat@gmail.com
}

\begin{abstract}
Abstrak
Tujuan dari penelitian ini adalah untuk mengetahui jenis kesalahan yang dilakukan oleh mahasiswa dalam membuat karangan berbentuk karangan narasi bahasa Inggris; untuk mengidentifikasi berbagai faktor kesalahan dalam penulisan; untuk mengoreksi kesalahankesalahan penulisan yang dilakukan oleh mahasiswa dan mahasiswi; untuk meningkatkan kualitas pengajaran yang sesuai dengan kurikulum dan silabus serta mendapatkan data dan penjelasan tentang kesulitan dalam belajar bahasa Inggris, khususnya dalam menyusun konjungsi karangan narasi dalam bentuk bahasa Inggris. Metode yang digunakan dalam penelitian ini adalah metode deskriptif yaitu suatu metode yang mencoba memberikan data dan penjelasan dengan cara memberikan catatan, menganalisis, menafsirkan keadaan saat ini. Ciri khas metode deskriptif adalah suatu metode dengan menggunakan data yang ada, fokus pada masalah dan variabel yang tidak dimanipulasi oleh peneliti. Penelitian ini dilakukan dengan tes penulisan karangan narasi dengan menggunakan bahasa Inggris. Setelah menganalisis data, hasil penelitian menunjukkan bahwa kesalahan dalam bentuk koordinasi konjungsi adalah 33,3\%, sedangkan kesalahan subordinat konjungsi adalah 66,7\%.
\end{abstract}

Kata Kunci: kesalahan sintaksis, konjungsi, teks naratif

\begin{abstract}
The aims of this research are to know the errors made by the learners on their English narrative composition; to identify the factors made the errors by learners; to identify the errors made by the learners; to correct the errors which have been made; to improve the teaching quality appropriating the curriculum and the syllabus; as well as to get the data and the explanation about the difficulties in studying English especially in arranging the conjunction of English narrative composition. The method used in this research is descriptive method that gives the data and the explanation about the recent symptoms of the errors made by the learners. The descriptive method consists of the ways in giving the note, the analysis and the interpretation about the recent condition. The characteristic of the descriptive method is to give the existence of the data which is straight to the problems as the recent variables are not manipulated. The research was carried out by conducting a written test of English narrative composition for the learners. After analyzing the data, the findings point out that the errors of coordinate conjunction are $33.3 \%$ and the subordinate conjunction is $66,7 \%$.
\end{abstract}

Keywords: syntactical error, conjunctional, narrative text 


\section{INTRODUCTION}

Just as birds have wings, men have language. The wings give the bird its peculiar aptitude for aerial locomotion. Language enables man's intelligence and passion to acquire their peculiar characters of intellect and sentiment (Blair, 1990)

There are some kinds in learning English such as; listening, speaking, writing, and reading. Writing is the most difficult part in learning English as what we say is different with what we write. The writing skills are complex and certainly difficult to teach, requiring not only of grammatical and theoretical devises but also conceptual and judgmental elements (Heaton, 1998).

Some factors making writing in English looks difficult, such as spelling, vocabulary and grammar. There are many aspects in grammar that should be mastered by the learners which can make some errors in learning English.

Writing is also concerned about the linguistics because "Linguistics is the scientific study of language",(Todd, 1987). In linguistics there are branches of the linguistics which one of them has the specific purpose that also help the learners in learning writing. "With writing, on the other hand, language competence involves the association of a meaning with a sign, a visual symbol", (Todd, 1987). Thus the study of the language will involve the learners in appraisal of all of the following levels of the language: (1) language, (2) phonology studies about sounds, (3) morphology studies about meaningful combination of sounds, (4) lexis studies about words, (5) syntax studies about meaningful combination of words, (6) semantic studies about meaning, (7) discourse studies about how syntax is combined

Any language has its own system which is different from one another. As a foreign language, the system of English is different from Indonesian language. Therefore, English is considered difficult to be learned. That it still remains to be shown that the process of learning second language is fundamentally different nature from the process of primary acquisition (Corder, 1975).

As the learner of foreign language, students especially from English department expect to master English not only in one skill but also in any kinds of skills, such as listening, speaking, and writing. However, they still have some difficulties using them. Something like error in applying their second language as like English. We live in an imperfect world; consequently, errors will always occur in spite of our best effort. It seems reasonable they make some errors (Corder, 1975).

Students' errors may occur in different components of language: in Grammar, lexicon, or pronunciation. In other words, students' errors occur in different linguistics categories such as phonology, morphology, syntax, and discourse.

One language component which is crucial to be considered is grammatical structure. One of which is morphology. Morphology is essentially the grammar of words and deal with form of words, the relation between take and took, dog and dogs and etc.

Syntax is related with the term "grammar", which is used in British linguists and "syntax" is used by many Americans. Syntax discusses about phrase, clause and sentence. Discourse analysis is concerned with the investigation of the language, both written and oral, as it is actually as opposed to an abstract system or structure of language. Discourse analysis references both a theory of language use, language use as not neutral but invested, and a method for analyzing language in use.

Discourse analysis has two components. One is the investigation of patterns in language use. The second relates to patterns of language use as activity or process. The 
aim of discourse analysis is to produce an analysis or "explanatory critique" of how and to what purpose language use is invested through the deployment of specific textual features, such as lexical, grammatical, and semantic, in order to facilitate understanding of its effects and the possibility of resistance to that investment.

Discourse analysis (DA), or discourse studies, is a general term for a number of approaches to analyzing written, spoken, signed language use or any significant semiotic event.

The objects of discourse analysis-discourse, writing, talk, conversation, communicative event, etc.- are variously defined in terms of coherent sequences of sentences, propositions, speech acts or turns-at-talk. Contrary to much of traditional linguistics, discourse analysts not only study language use beyond the semen ce boundary, but also prefer to analyze naturally occurring language use. and not invented examples. This is known as corpus linguistics; text linguistics is related. The essential difference between discourse analysis and text linguistics is that it aims at revealing socio-psychological characteristics of a person/persons rather than text structure

Discourse analysis has been taken up in a variety of social science disciplines, including linguistics, sociology, anthropology, social work, cognitive psychology, social psychology, international relations, human geography, communication studies and translation studies, each of subject to its own assumptions, dimensions of analysis, and methodologies. Sociologist Harold Garfinkel was another influence on the discipline.

According to (Murthy, 2003), phrase is a group of words which does not make complete sense; clause is a group of words which forms a part of sentence and contains a subject and a verb; sentence is a group of words which makes complete sense.

Based on the problems above, morphology, syntax and another error will be analyzed. By analyzing the errors, we hope that the errors done by the learners can be corrected so the errors in writing won't be happened especially in conjunction.

\section{Theoretical Review}

The Nature of Syntax

In linguistics, syntax the study of the rules that govern the ways in which words combine to foot phases, clauses, and sentences. Syntax is one of the major compacts of grammar. Noam Chomsky (dalam Dwijatmoko, 2002)stated that: Syntax is the study of the principles and processes by which sentences are constructed in particular languages. Syntactic investigation of a given language has as its goal the construction of a grammar that can be viewed as a device of some sort for producing the sentences of the language under analysis.

Based on World English Dictionary, stated that: (1) the branch of linguistics Thai deals with the grammatical arrangement of words and morphemes in the sentences of a language or of languages in general, (2) the totality of facts about the grammatical arrangement of words in a language, (3) a systematic statement of the rules governing the grammatical arrangement of words and morphemes in a language, (4) logic a systematic statement of the rules governing the properly formed formulas of a logical system, (5) any orderly arrangement or system

Loretto Todd stated that British linguists often use the term 'grammar' for the same level that is referred to as 'syntax' in many Americans. The different in terminology will become clear when various models of grammar are examined. Syntax commonly studies about the phrase, the clause and the sentence. 
(a) The phrase is a group of words which does not make complete sense. In the east with love and care. (b) The clause is a group of words which forms a part of a sentence and contains a subject and a verb. Where she was born when I saw him. (c) The sentence is a group of words which makes complete sense Honesty is the best policy what are you doing? (Murthy, 2003)

Conjunctions are also part of Syntax discussed in this thesis. They are also part of speech. The eight parts of speech are verbs, pronouns, adjectives, adverbs, prepositions, conjunctions and interjections. A conjunction connects words, phrases or clauses. Incoherent or mis punctuated sentences often result from misused conjunctions. There are three kinds of conjunctions: coordinate, subordinate and conjunctive adverbs (also called logical connectives).

Coordinate conjunctions (and, but, nor, for) join words, phrases and clauses of equal importance:

Words : Silk and velvet are my favorite materials.

Phrases : Living in pain or dying in peace was his choice.

Clauses : George continued to make money, but he was miserable.

A special type of coordinate conjunction is the correlative conjunction, which also joins elements of equal importance but also occurs only in pairs, such as: not only ... but also, neither... nor, both ... and.

Example: $\quad$ Not only did he buy a Porsche, but he also paid cash for it.

Neither she nor her husband appeared at the ceremony.

Both my father and my grandfather agree with me.

Subordinate conjunction (if because, when, since, where, while, whereas, after, before. until as if) are used to join subordinate clauses with independent clauses, as:

Example: $\quad$ Felice studies because she is ambitious.

If it rains, we must buy an umbrella.

However, place of subordinate conjunction before an independent clause and you will have a sentence fragment-a transformation often overlooked by the student writers:

Example: The man stood at the door, (independent clause)

While the man stood at the door, (fragment caused by subordinate conjunction)

Such a fragment can be corrected by attaching it to an independent clause:

Example: While the man stood at the door, the dog barked.

The dog barked while the man stood at the door.

Relative pronouns can function as subordinate conjunctions.

Example: We blamed the man who was driving without a license. Most people feel confident that our economy will not Conjunctive adverbs (however, consequently, moreover, besides, on the other hand, that is to say. nevertheless, meanwhile, indeed, anyhow, hence, henceforth, then) are adverbs used to connect independent clauses. Always place a semicolon before and $a$ comma after a conjunctive adverb that connects two independent clauses.

Example: The tickets are three dollars apiece; however, members of the club pay only two dollars.

The sky was dark and cloudy; nevertheless, we pressed onward. 
A comma should be used before and after the conjunctive adverb when the conjunctive adverb is parenthetical.

Example: $\quad$ My friend drove her car to the party; I, however, took the bus.

The other half of the restaurant, meanwhile, stood empty and forsaken

The use of yet and so as coordinate conjunctions has been more or less accepted in informal writing. However, careful writers use yet only as a logical connective and seldom use the anemic so.

\section{The Nature of Composition}

Writing is the most difficult part in English subject as what it is said different from what it is written. Ron White and Valerie Ardnt (dalam Li et al., 2019) stated, "Writing is far from being a simple matter of transcribing language into written symbols; it is a thinking process in its right." so, before the learners starting to write m English composition, they should master the English pattern correctly.

A composition is a group of closely related paragraph that develop a single idea. Writing a composition with vocabulary and structure which the student has either learnt to use orally or written exercises for each lesson (Crystal, 1997). These exercises may be of various types. The range from filling blanks to the composition and may be modification, sentences composition and paragraph writing."

So, the theory of the composition based on Mc. Dougal is the activity of writing which is started by mastering words and the grammar itself.

There are 4 kinds of compositions; they are argumentation, description, exposition and narration.

Argumentation is used in persuading and convincing; it is closely related to exposition and is often found combined with it. Description is used to create a visual image of people, places and even of units of time-days, time of day or seasons, exposition is used in giving information, making explanation, and interpreting meanings and narration is the form of writing used to relate the story of acts or evens (Wishon, G.E, \& Burks, 1980).

Narratives are stories. Narratives are plots. They are essays that tell a story, hopefully in an interesting way. that also convey themes. Often, if you are asked to write a narrative essay, you will not be asked to research a theory or topic. Rather, you will be asked to use your imagination instead of a bibliography. You may need to research for this narrative essay; nonetheless, the writing of it may come more easily to you for you do not need to quote specific words from primary sources. Here is a short reference guide on how to write the narrative essay: (1) Decide on a topic, (20 Discuss the topic with your peers either in class or in a group discussion or private tutorial, (3) Brainstorm several different ways the narrative can go, (4) Start writing, (5) Do not stop writing. Let your writing flow onward in a stream of consciousness type of way, (6) Reread the essay. (7) Edit for grammar and the technical rules of writing. (8) Let someone else edit/read over your essay for content and grammar.

Before you begin writing your narrative essay, it helps to brainstorm ideas for where you want your narrative to go. Because you are able to invent plot, you can write anything your imagination invents. As a result, you will want it to appear coherent and plausible. Many narrative writers use diagrams to begin. Start with the main idea (person, subject, object), and circle it Then, write lines from the circle for descriptive words for that one main idea. Let each spoke continue outward farther and farther, until you have a 
spider-looking diagram with many thoughts. You can pick any of those for your narrative and follow it.

Ultimately, you will have written a narrative (story) that reads more pleasurably than academically. Because of the nature of the narrative essay, you will usually be assigned to write one only in creative writing or literature seminars. Often in composition and freshman writing courses, people also are assigned narrative essays to write. If you are given this assignment, it is important to remember that a narrative essay is still an essay. It is not a novel excerpt or a novella. It is a self-contained essay with a theme (or thesis) still at the focus of the writing. And even though it is more creative than academic, grammar and syntax are still vital to the success of the essay. The research was conducted at the first and third semester at Pertiwi School of Foreigh Language Jakarta at Cililitan East Jakarta

\section{The Nature of Writing}

The writing is good when it gives information or messages clearly and creates effective verbal dialogue to readers. It aims to give point of view of the ideas in text where it organizes in different way of writing such as narration, description, exposition, and argumentation. When students write a paragraph, they try to explore what they are thinking in mind, and they also concern with the language, meaning, and the structural of context related to English language acquisition as second or foreign language. As Gould Diyanni. and Smith state that "Writing is an effort to create a dialogue with readers, and it involves exploring our relationships to our readers in much the same way that exploring our relationships to people we talk to."

Thus, writing must be related to the content, the language and grammatical rules. In order to avoid misunderstood, the students have to use correct sentences by creating a well written text and giving attention to the arrangement of words their composition to express their idea and to give the value of the writing to readers. According to Hyland:

Essentially, writing is seen as a product constructed from the writer's command of grammatical and lexical knowledge, and writing development is considered to be the result of imitating and manipulating models provided by the teacher. For many who adopt this view, writing is regarded as an extension of grammar-a means of reinforcing language patterns through habit formation and testing learners' ability to produce well-formed sentences.

In regard to the review of writing theory, Hyland states that writing is a series of sentences with appropriate grammar. It develops become a text or essay which has meaning and is provided by varying words. The writers produce an essay by developing the ability in certain grammar and lexical knowledge.

Celce and Olshtain state:

"Writing is the production of the written word that results in a test, but the text must be read and comprehend in order for communication to take place. The writer, in other words, communicates his/her ideas in the form of a written text from which a known or unknown reader will eventually extract the ideas and their meanings."

Hartoyo states: "Academic writing is a three-level course focusing on exposing some fundamental grammatical features and their usage and applications to writing. White claims:

"We must also write in order to communicate something to our intended audience, and since this audience is not physically present, what we write must be as clear, precise and unambiguous as possible. In short, we must produce a piece 
of discourse which embodies correctness of form, appropriateness of style and unity of theme and topic".

Developing writing is related to the writer's knowledge of language and writing exposure. Writing process is the way the writers give their ideas and messages to readers in the form of text. The writers present their ideas in various ways of writing such as narration, description, classification, comparison and contrast, argumentation and etc. First narration is a basic writing strategy for presenting past event or activities. It can be used for a variety of purposes such as to illustrate and support ideas with anecdotes, to entertain readers with revealing stories, to analyze causes and possible effects with scenarios, and to explain procedures with process narrative. Second, description is a strategy used to create a dominant impression. For example, students describe a place in order to set a scene and make readers aware of its atmosphere and to describe people to show a kind of person's performance. Third, classification is aimed to classify number of hems or ideas into a small number of classes. In a classification of paragraph, it is important to set up adequate categories and define want goes into categories. Fourth, comparison and contrast are to compare similar aspects or to contrast different aspects of two subjects, people or things. At last, argumentation is to argue ideas or opinion by giving some argues to proof the concept or research. A good paragraph must give readers complete information and unified by a controlling idea. It is organized form and can be understood what the paragraph is going to be about. As Boardman states:

"A paragraph is a group tells works together to develop a main idea. Paragraphs are organized differently depending on their purposes. There are three main types of paragraphs in English: narrative, descriptive, and expository."

A narrative paragraph tells a story or a series of events. It tells what person or thing did during a particular period of time. As White states:

In narrative it is activities which are important: in description it is things. And in describing things we are usually more concerned with the noun rather than the verb phrase. Thus, description gives us a reason for teaching features of the noun phrase winch, while occurring in other uses of the language, are of particular importance and frequency in describing things, people and places.

A descriptive paragraph is to describe what something looks like, such as a place, a person, and an animal. The expository paragraph is to explain something to the reader.

\section{The Nature of Errors}

Errors are defined as any deviation from a selected norm of language performance, no matter what the characteristic or causes of the deviation might be. They are those parts of conversation or composition that deviate from some selected norm of mature language performance (Dulay, 1992). Brown (1987: 170) defined an error as noticeable deviation from the adult grammar of native speaker, reflecting the interlingual competence of the learner. Despite of the imperfection, errors are not seen as signs of failures.

According to Corder, errors are breach of the code, meaning that they are against the grammatical rules of the language, which result in acceptable utterances. They are not physical failures but the sign of imperfect knowledge of the code. Errors are systematic and provide the researcher insight into the learner process.

\section{RESEARCH METHOD}

This research was conducted by using qualitative research. Qualitative research is one of kinds of research that have function to look object condition naturally. In 
qualitative research, the researcher is the most important key. In the other word, qualitative research is main participant in involves examining and reflecting on the less tangible. The aims of this research are to know the errors made by the learners on their English narrative composition; to identify the factors made the errors by learners; to identify the errors made by the learners; to correct the errors which have been made; to improve the teaching quality appropriating the curriculum and the syllabus; as well as to get the data and the explanation about the difficulties in studying English especially in arranging the conjunction of English narrative composition.

\section{RESULT AND DISCUSSION}

The discussion about errors found in the learner's English narrative composition. The samples were taken from 37 learners' English narrative composition.

Table 1 Syntactical Level (coordinate and subordinate conjunction)

\begin{tabular}{|c|c|c|c|}
\hline No & Student's sentence & Kind of error & Reconstruction \\
\hline 1 & $\begin{array}{l}\text { We are resident of Jakarta always } \\
\text { expecting Jakarta is save }\end{array}$ & $\begin{array}{l}\text { coordinate } \\
\text { conjunction }\end{array}$ & $\begin{array}{l}\text { We are residents in Jakarta and } \\
\text { expect Jakarta is save }\end{array}$ \\
\hline 2 & $\begin{array}{l}\text { Distance from Jakarta a to Yogyakarta } \\
\text { by road thirteen hour }\end{array}$ & $\begin{array}{l}\text { Coordinate } \\
\text { conjunction }\end{array}$ & $\begin{array}{l}\text { The distance between Jakarta } \\
\text { and Yogyakarta by road is } \\
\text { thirteen hours }\end{array}$ \\
\hline 3 & $\begin{array}{l}\text { Distance an attack from Jakarta to } \\
\text { Banjarmasin that is one hour twenty- } \\
\text { five minutes pass through at flight }\end{array}$ & $\begin{array}{l}\text { coordinate } \\
\text { conjunction }\end{array}$ & $\begin{array}{l}\text { The distance between Jakarta } \\
\text { and Banjarmasin is one hour } \\
\text { twenty-five minutes by plane }\end{array}$ \\
\hline 4 & $\begin{array}{l}\text { Distance from Jakarta to Yogyakarta } \\
\text { by road thirteen hour }\end{array}$ & $\begin{array}{l}\text { coordinate } \\
\text { conjunction }\end{array}$ & $\begin{array}{l}\text { The distance between Jakarta } \\
\text { and Yogyakarta by road is } \\
\text { thirteen hours }\end{array}$ \\
\hline 5 & $\begin{array}{l}\text { At } 13.15 \text { we had lunch together after } \\
\text { that went to pray and find the room for } \\
\text { take a rest }\end{array}$ & $\begin{array}{l}\text { coordinate } \\
\text { conjunction }\end{array}$ & $\begin{array}{l}\text { At } 13.15 \text {, we had lunch together } \\
\text { and prayed and went the room } \\
\text { for taking a rest }\end{array}$ \\
\hline
\end{tabular}

Based on the examples above, the students showed that the errors happened in learners' English narrative composition about coordinate conjunction. The researcher analyzed the students don't use the coordinate conjunction properly. The errors happened because they arelack of their knowledge about coordinate conjunction.

Table 2 The errors happened in learners' English narrative composition about coordinate conjunction

\begin{tabular}{|c|l|l|l|}
\hline 1 & $\begin{array}{l}\text { If the citizen don't have ID cards can } \\
\text { sent to them regent }\end{array}$ & $\begin{array}{l}\text { Subordinate } \\
\text { conjunction }\end{array}$ & $\begin{array}{l}\text { If the citizen don't have ID cards, } \\
\text { they will bring back to their } \\
\text { village }\end{array}$ \\
\hline 2 & $\begin{array}{l}\text { One place make tourist interesting is } \\
\text { Bali Beach Kuta }\end{array}$ & $\begin{array}{l}\text { Subordinate } \\
\text { conjunction }\end{array}$ & $\begin{array}{l}\text { One place which makes tourist } \\
\text { interesting is Kuta beach in Bali }\end{array}$ \\
\hline 3 & $\begin{array}{l}\text { Jakarta is the big city other co mpare } \\
\text { with another city in Indonesia }\end{array}$ & $\begin{array}{l}\text { Subordinate } \\
\text { conjunction }\end{array}$ & $\begin{array}{l}\text { If we compare Jakarta with other } \\
\text { cities in Indonesia, Jakarta is the } \\
\text { biggest }\end{array}$ \\
\hline 4 & The people in Jakarta are nice & $\begin{array}{l}\text { Subordinate } \\
\text { conjunction }\end{array}$ & $\begin{array}{l}\text { people who live in Jakarta are } \\
\text { nice }\end{array}$ \\
\hline 5 & When evening the weather is snow & $\begin{array}{l}\text { Subordinate } \\
\text { conjunction }\end{array}$ & $\begin{array}{l}\text { When in the evening, the weather } \\
\text { is snow }\end{array}$ \\
\hline
\end{tabular}




\begin{tabular}{|c|l|l|l|}
6 & Seattle is town famous with seafood & $\begin{array}{l}\text { Subordinate } \\
\text { conjunction }\end{array}$ & $\begin{array}{l}\text { Seattle is a town which is famous } \\
\text { its seafood }\end{array}$ \\
\hline 7 & $\begin{array}{l}\text { Many people to Ancol specially for } \\
\text { outbound }\end{array}$ & $\begin{array}{l}\text { Subordinate } \\
\text { conjunction }\end{array}$ & $\begin{array}{l}\text { Many people who come to } \\
\text { Ancol is especially for outbound }\end{array}$ \\
\hline 8 & $\begin{array}{l}\text { Language in use is commonly use } \\
\text { language row }\end{array}$ & $\begin{array}{l}\text { Subordinate } \\
\text { conjunction }\end{array}$ & $\begin{array}{l}\text { Their language which is } \\
\text { commonly used is row language }\end{array}$ \\
\hline 9 & $\begin{array}{l}\text { Jakarta is the one of place very } \\
\text { crowded and busy in Indonesia }\end{array}$ & $\begin{array}{l}\text { Subordinate } \\
\text { conjunction }\end{array}$ & $\begin{array}{l}\text { Jakarta is a place which is very } \\
\text { crowded and busy in Indonesia }\end{array}$ \\
\hline 10 & $\begin{array}{l}\text { If not we are keep cultures, who else? } \\
\text { conjunction }\end{array}$ & $\begin{array}{l}\text { Subordinate } \\
\text { condo else? }\end{array}$ \\
\hline
\end{tabular}

Based on the examples above, the students showed that the errors happened in learners' English narrative composition about subordinate conjunction. The researchers analyzed that:

1. the learners don't understand that after subordinate conjunction happened in the first sentence should be followed by comma,

2. the students don't use the subordinate conjunction properly the usage of subordinate conjunction "who" is for people the usage of subordinate conjunction "which" is for thing the usage of subordinate conjunction "where" is for place, etc

\section{CONCLUSION}

Based on the research above, some analysis about the errors made by the learner can concluded that the learner do not understand about subordinate conjunction, the learner do not understand about coordinate conjunction, the learner don't understand the parallelism, recognizing the characters of the learners' error. most of them haven't mastered yet the target language well so they tended to make mistakes in their writing, most of the learners' errors happened in the textual errors, most of them influenced by their mother tongue, in other hand, they transferred directly to their mother tongue even with grammatically wrong

\section{REFERENCES}

Blair, C., \& Fromkin, R. (1990). An Introduction to language. Holt Rinehart and Winston.

Corder, S. P. (1975). Error Analysis and Interlanguage. Oxford University Press.

Crystal, D. (1997). English as a global language. Cambridge University Press.

Dulay, H. (1992). Language Two. Longman Group.

Dwijatmoko, B. . (2002). English Syntax. Sanata Dharma University Press.

Heaton, J. (1998). Writing English Language Test. Longman. 
Li, K. L., Razali, A. B., \& Baki, R. (2019). Writing narrative essays using e-book writing software: Analyses of students' digital written works. Journal of Asia TEFL, 16(4), 1289-1304. https://doi.org/10.18823/asiatefl.2019.16.4.14.1289

Murthy, J. (2003). Contemporary English Grammar for Scholar and Students. Book Palace.

Todd, L. (1987). An Introduction to Linguistics. Longman.

Wishon, G.E., \& Burks, J. M. (1980). Let's write English. Litton Educational Publishing. 